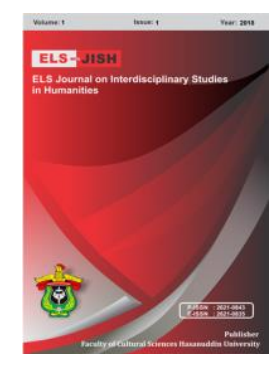

ELS-JISH

ELS Journal on Interdisciplinary Studies on Humanities

Volume 1 Issue 1, 2018

ISSN (print) : 2621-0843

ISSN (online) : 2621-0835

Homepage : http://journal.unhas.ac.id/index.php/jish

\title{
Escapism as Reflected in Tennessee William's The Glass Menagerie
}

\author{
Nensia ${ }^{1}$ \\ E-mail:nensia.s@gmail.com
}

\begin{abstract}
Escapism is a part of psychology which in this research connected into literature as an interdisciplinary study which shows inclination of human personality to seeking for a way out or escape from unpleasant realities. The aim of the research was to describe the characters got acquainted with escapism and the way the characters' cope with escapism in their daily life. The research employed a descriptive qualitative method with psychoanalytical approach of Sigmund Freud's personality structure from anxiety theory, defense and problem solving mechanism. Data sources were primary and supporting data. The primary data were taken from Tennessee William's The Glass Menagerie, and supporting data were taken from the books, journals, articles, and internet sources. The research indicated that each character experienced anxiety that made them got acquainted with escapism. They had their own way in dealing with escapism through defense and problem solving mechanism. Some characters solved emotional problems with negative mechanism consciously or unconsciously, and others handled emotion with positive mechanism, therefore the result were also positive.
\end{abstract}

Keywords: The Glass Menagerie, Escapism, Anxiety, Defense Mechanism, Coping Mechanism.

How to cite: Nensia. (2018). Escapism as Reflected in Tennessee William's The Glass Menagerie. ELSJournal on Interdisciplinary Studies in Humanities, 1(1), 110-116

\section{Introduction}

Each person in everyday life must be dealt with strain, depression, or unpleasant situation in life. These psychology symptoms lead an individual seeking for a way out to escape or release the pain, tension, and depression. This circumstance is called as escapism. The history of escapism began as the result of society's depression after the World War I.

It is known that the result of World War I is the economic downturn in America. It causes the stock market crashed in 1929 (Rauchway, 2008). All people suffered by the mass poverty whether they were rich or poor. It becomes a depressing era called as The Great Depression.

Despite of this depression, the Americans tried to escape or get out of their problem by their own way. They intend to forget their depression and the harsh reality that they have to deal within their daily life. The way they choose was through entertainment. They entertained their selves by enjoying magazines, radio, music, and movies as well which is later known as the phenomenon of escapism (Brinkley, 1998).

${ }^{1}$ Faculty of Cultural Sciences, Hasanuddin University 
As an essential part, these entertainments show that the American succeed to get away from their real life problems through avoidance and distraction. It shows the values of American individualistic and cooperation. Thus the history where escapism begin. The crucial thing is these American's values brought by the author into the form of literary works. Among these authors were John Steinbeck, Ernest Hemingway, and Scotts Fitzgerald as well but one of the greatest playwrights at that time was Tennessee William.

When reading William's drama, for reader who has known about William's personal life, must be grasped that his drama is much more similar to author's personal experience. It may lead reader to conclude that the drama is a portrait of the author's life background. It also happened to writer which find this as interesting aspect. Therefore, in this writing, the chosen literary work to be analyzed is a drama by Tennessee William, entitled The Glass Menagerie, published in 1944.

As one of William's famous dramas, The Glass Menagerie was his first successful drama which made him the American most highly regarded playwright. It won the New York Drama Critics Circle Award as Best American Play (Loewenberg, 1996). Regarding to this drama, Tariq, in her journal (2010), also chose The Glass Menagerie as the object of her research. Her journal also brings out the impact of The Great Depression on a typical Southern-American family as it is much alike with the writing of this thesis research. Besides that, another study which also represents similarity with this research is a journal which is conducted by Sharma (2014), through psychoanalysis.

Actually there is an interesting fact in the drama where it is believed as an autobiographical drama (Bloom, 2007). In Bloom's book Bloom's Guide: Tennessee William's The Glass Menagerie (2007) can be seen that the Wingfield family who is the family characters in the drama have similarities with the members of the author's family in real life, William family. Amanda Wingfield represents Edwina William where in the reality she was obsessed by her pride and her nostalgia for patrician Southern life (she was a member of the Daughters of the American Revolution). It is applied in the drama where in unpleasant situation, Amanda Wingfield would reveal her pride of her status as a noble Southern woman who has received seventeen gentlemen callers in one night. It was turned out to be her obsession to Laura's marriage. Tom Wingfield represents Tennessee William who has similarities as well; the depression that he felt of his mother's constant nagging and obsession of becoming a writer then to reach the dream, he left his job in a shoes factory. Laura Wingfield represents Rose William whose life suffered a mental problem, while in the drama she is described as a crippled girl who also shuts out herself from the outside world or society and being obsessed for her glass figurines.

The writer views these similarities that each character deals with avoidance, distraction, obsession, inclination which become their hobby as a media to get away or escape from the unpleasant situation that they have to deal with in their life. In the other word, the intention is looking for the comfort zone as a relief from unpleasant realities by seeking entertainment or disengaging fact to engaging fantasy. These show the circumstance of escapism concluded by Oxana (2015), Escapism: Current Studies and Research Prospects in Contemporary Psychology. Meanwhile, escapism by engaging fantasy has been conducted by Daniel (2013), which stated that the individual in The Glass Menagerie crushed by a mechanical society which is forced to seek relief from pain in memory of fantasy. It is the same way as what has been hypothesize in this analysis.

Thus, the theory of anxiety, defense and coping mechanism are needed in this research. The defense mechanism is marked down by Vaillant (1994), which stated that 
the psychological defense system is expressed often unknowingly in each person much like the immune system operates without our conscious awareness. Meanwhile the coping mechanism which is used in this research is based on Ballesteros \& Whitlock's Cornell research program (2009). It is used to minimize or tolerate the stress or conflict (Cumming et al., 1991). All those analysis, then alternate into the type of escapism (Evans, 2001).

From these descriptions, the writer is interested to analyze the escapism aspects in The Glass Menagerie by using the psychoanalytical approach. It includes anxiety of the harsh reality which is experienced by characters in the drama followed by avoidance or distraction into escaping the reality through psychological escapism of the character's condition in the drama. Therefore, the writer determines the title of this analysis is Escapism As It Is Reflected in Tennessee William's The Glass Menagerie.

\section{Research Method}

\subsection{Research Design}

The researcher uses descriptive qualitative method. Descriptive qualitative method presents the object analysis descriptively without using scores or quantitative category. It looks the object as the result of thinking and interpretation of the observation. The aim of descriptive method is describing or explaining the whole phenomenon of the object study. In this research, this method is used to elaborate the escapism in The Glass Menagerie.

\subsection{Source of Data}

This research uses primary and secondary data. The primary data is collected from The Glass Menagerie reprinted in 1945 through marking, rewriting some problems from this drama, and looking for the related of the study. While the secondary data support the primary data. It is some literatures or some relevant information that will support the research. For instance, some references that have correlation to the topic of the research, collected from other sources, such as books, journals, thesis, electronic articles, encyclopedia, videos, dictionaries and other professional writings as well.

\subsection{Method of Data Collection}

The researcher tends to use library research method. It involves several steps. The first is through reading the text repeatedly then it is followed by listing which means making the list of statements that related to the title of this research. Next step is through collecting the references which are considered relevant to this research. The last step is computing data and reporting them. By collecting the data, the researcher does not only used library research, but also note taking method and quotes to notice and show the data.

\subsection{Method of Data Analysis}

In this research, the researcher uses method of data analysis to support the analysis. In analyzing the play, the researcher uses anxiety, defense mechanism and coping mechanism theories as escapism through the characters depicted in the play. These theories enable the mind to reach comprehension to conflicts in the drama that reflects the escapism.

\section{Findings}

As has been explained previously, the researcher analyzes the escapism in the play. After reading the play, the researcher finds that there are anxieties experienced by the characters as causes that make the characters acquainted with escapism. These types 
of anxieties are realistic, neurotic, and moral anxiety. The description about them can be seen in the following quotations.

\section{Realistic Anxiety}

Realistic anxiety is in the form of fear caused by external world. It occurs in response to a real threat to the person.

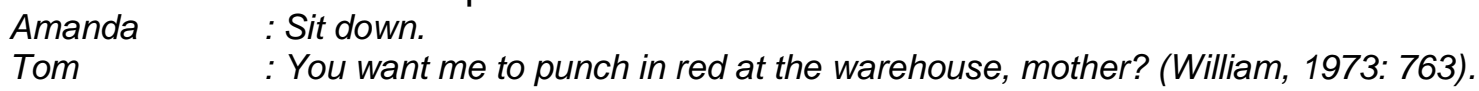

\section{Neurotic Anxiety}

Neurotic anxiety is driven by fear of punishment that will result from expressing Id's desires without proper sublimation. It is caused by direct conflict between the id and the ego. The danger is if the ego lose control over the id.

Jim : Somebody - ought to -

Ought to - kiss you, Laura! [His hand slips slowly up her arm to her shoulder. He suddenly turns her about and kisses her on the lips.] (William, 1973: 781)

\section{Moral Anxiety}

Moral anxiety felt when the threat comes not from the outside of physical world, but from the internalized social world of Superego. It is in a form of fear of violating moral or societal codes.

Tom : I haven't enjoyed one bite of this dinner because of your constant directions on how to eat it. It's you that make me rush through meals with your hawk-like attention to every bite I take. Sickening - spoils my appetite - all this discussion of - animal's secretion - salivary glands - mastication! (William, 1973: 753)

Above anxieties lead the characters possess defense mechanism as a means of protecting self against anxieties. It is defined as following:

\section{Introjection}

When people introject, they are identified with a person or object that they cannot separate that person or object from themselves. It makes people live in their own world.

Tom : She lives in a world of her own - a world of little glass ornaments, mother ... She plays old phonograph records and that's about all. (William, 1973: 768)

\section{Denial}

Denial means refusing to admit that something has happened. It avoids the strain or danger that will come up from something.

Laura : I'm crippled.

Amanda : Nonsense! Laura, I've told you never, never to use that word, why? You're not crippled, you just have a little defect - hardly noticeable, even! When people have some slight disadvantage like that, they cultivate other things to make up for it - develop charm - and vivacity - and - charm! That's all you have to do! (William, 1973: 757)

\section{Repression}

It is a process to pushing down unwanted ideas or desires to unconscious area. The purpose is to forget something that can cause strain or tension.

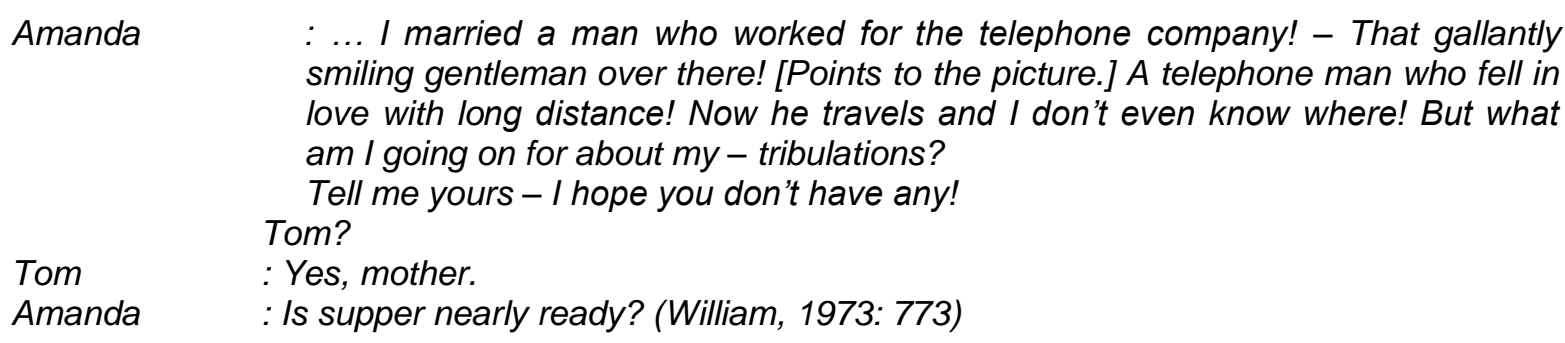

\section{Fixation-Regression}


This type of defense shows that an individual unable to move on from the glory of their past time. It is caused by the comfortable which is felt by an individual in the past.

Amanda: Sometimes they come when they are least expected! Why, I remember one Sunday afternoon in Blue Mountain.

Tom : I know what's coming!

Laura : Yes, but let her tell it.

Tom : Again?

Laura : She loves to tell it.

Amanda: One Sunday afternoon in Blue Mountain - your mother received - seventeen! Gentlemen callers! Why, sometimes there weren't chairs enough to accommodate the all. We had to send the nigger over to bring in folding chairs from the parish house. (William, 1973: 754)

\section{Escaping-Avoiding}

It is a form of defense which avoids direct conflict. The purpose is getting out of the unpleasant situation. The individual who possesses this mechanism should leave the place where the strain comes up.

Tom : I won't hear more, I'm going out!

Amanda: You come right back in

Tom : Out - out - out - Because I'm (William, 1973: 759)

Beside above defense mechanism, aim of this research is also analyzing the coping mechanism that applied by each character in this drama. It is shown in below quotations.

\section{Amanda Wingfield}

In order to dealing with her anxiety toward Laura's future, she asks help from Tom. In Ballesteros, it is called as seeking support from others. It is identified as positive coping mechanism.

Amanda: We have to be making some plans and provisions for her She's older than you, two years, and nothing has happened. She just drifts along doing nothing. It frightens me terribly how she just drifts along. (William, 1973: 763)

Amanda: Find out one that's clean-living, doesn't drink and ask him out for sister! (William, 1973: 764)

\section{Tom Wingfield}

Tom apologizes to his mother when his mother did not want to talk directly to him anymore. This is a good thing to do as it is identified as positive coping mechanism which is known as apologizing.

Tom : Mother, I-I apologize, mother. [Amanda draws a quick, shuddering breath. Her face works grotesquely She breaks into childlike tears.] I'm sorry for what I said, for everything that I said, I didn't mean it. (William, 1973: 762)

\section{Laura Wingfield}

She is identified as an extremely shy girl who unable to socialize with other people. Therefore, the way chosen by Laura in order to solve her problem is through negative coping mechanism, isolating self or withdrawal.

Amanda : I put her in business college - a dismal failure! Frightened her so it made her sick at the stomach. I took he over to the Young People's League at the church. Another fiasco She spoke to nobody, nobody spoke to her Now all she does is fool with those pieces of glass and play those worn-out records What kind of a life is that for a girl to lead? (William, 1973: 763)

\section{Jim O’Connor}

He takes coping mechanism in order to reduce the tension when his Id took control over his Ego. He already engaged to another girl but he kissed Laura right on her lips without any relationship. Therefore, he dares to tell the truth to Laura about his engagement. This is known as positive coping mechanism by telling the truth. 
Jim : No, Laura. I can't. [He rises from the sofa. As I was just explaining, I've got strings on me Laura, I've been going steady! I go out all of the time with a girl named Betty. She's a homegirl like you, and Catholic, and Irish, and in a great many ways we get along fine I met her last summer on a moonlight boat trip up the river to Alton, on the Majestic. Well-right away from the start it was-love! (William, 1973: 782)

\section{Discussion}

The result of this research shows the escapism as it is reflected in the drama, The Glass Menagerie. The characters experience the causes that makes them acquainted with escapism through anxieties. Then, the way the characters cope with escapism is through defense and coping mechanism.

Thus, the writer found that the characters in the play experience three types of anxiety; realistic anxiety experienced by Amanda and Tom, neurotic anxiety experienced by Tom and Jim, and moral anxiety experienced by all of the characters. Amanda, Tom, Laura and Jim as well. These anxieties then become the causes that make the characters get acquainted with escapism.

Besides anxiety, the writer also found that the characters in the play possess five types of defense mechanism; Introjection which is used by Tom and Laura, denial, repression and fixation-regression which is used only by Amanda, and the last is escapingavoiding which is used by Tom and Jim. These mechanisms show the way the characters' cope with escapism in their daily life.

Meanwhile, the characters also possess coping mechanism in their own way. For instance, Amanda cope with the problem by seeking support from others, telling the truth and blaming others. Type of coping response employed by Amanda is emotional response and the type of escapism is hyperactive. Tom cope with the problem through blaming others, write things down, watch movies, learn forgiveness and running away. Type of coping response employed by Tom is emotional and behavioral response and the type of escapism is hyperactive, avoidance, and extreme. Laura cope with the problem through fantasizing, low expectation and being passive. Type of coping response employed by Laura is mental, emotional, and physical responses and the type of escapism is passive and avoidance. Jim cope with the problem by telling the truth and the type of escapism is hyperactive. These mechanisms show the way the characters' cope with escapism in their daily life.

\section{Conclusion}

Based on the research result, the writer may conclude that all the characters in The Glass Menagerie experience anxiety of their problem and harsh or unpleasant reality that they have to deal in their life. These anxieties make them possess defense and coping mechanism in order to get away or escape from their problem, harsh reality and unpleasant situations. They try to escape from that situation through distraction, tendency, inclination, activity or hobby, and habitual diversion as well. It shows the existing of escapism in The Glass Menagerie. In this regard, each human being has their own way in dealing with escapism in their life. Whether it is through defense or coping mechanism. But an individual is seldom only using one type of defense or coping mechanism. If the first mechanism is not enough to deal with the problem, then they will try another type of mechanism. Human behavior shows the result of their emotion in coping the problems. If it is handled positively, then the result will be positive. On the contrary, if it is handled negatively, then the result will be negative. In this research, the writer has carried out the analysis on anxiety, defense mechanism and coping mechanism as what is called in 
psychoanalysis as escapism which is reflected in this drama. There are many types of defense mechanisms which are interesting for the next subject to be explored by the researcher as further studies.

\section{References}

Ballesteros D. \& Whitlock J.L. (2009). Coping: Stress management strategies. The Fact Sheet Series, Cornell Research Program on Self-Injury and Recovery. Cornell University: Ithaca, New York.

Bloom H. (2007). Bloom's Guide: Tennessee William's The Glass Menagerie. New York: Chelsea House copyright (C2007 by Infobase Publishing.

Brinkley A. (1998). Culture and Politics in the Great Depression. Waco, Texas: Baylor University \& Markham Press Fund.

Cummings E. et al. (1991). Life-span Developmental Psychology: Perspectives on Stress and Coping. p. 92. ISBN 978-0-8058-0371-6.

Evans A. (2001). This virtual life; Escapism and Simulation in our Media World. London: Fusion Press, Inc.

Daniel J. (2013). The World of Illusion in Tennessee William's The Glass Menagerie. International Journal of Innovative Research in Science and Technology, 2(11)

Loewenberg S. A. (1996). Alive \& Aloud: Teacher's Study Guide The Glass Menagerie. B1996 L.A Theatre Works All rights reserved.

Oxana O. (2015). Escapism: Current Studies and Research Prospects in Contemporary Psychology. Austrian Journal of Humanities and Social Sciences 3, 4(1): 103105.

Rauchway E. (2008). The Great Depression and The New Deal. New York: Oxford University Press, Inc.

Sharma S. (2014). Concept of morality in Tennessee William's The Glass Menagerie and A Streetcar Named Desire. International Journal on Studies in English Language and Literature, 2(9): 114-117.

Tariq H. (2010). American Dream and Its Fallibility in Tennessee William's The Glass Menagerie. International Journal of Arts and Humanities 38. 38: 31.

Vaillant G. (1994). Ego mechanisms of defense and personality psychopathology. Journal of Abnormal Psychology, 103(1): 44-50. 